Article

\title{
Wastewater Treatment Plant: Modelling and Validation of an Activated Sludge Process
}

\author{
Francesco Calise ${ }^{1}$,, Ursula Eicker ${ }^{2}$, Juergen Schumacher ${ }^{2}$ and Maria Vicidomini ${ }^{1, *}$ \\ 1 Department of Industrial Engineering, University of Naples Federico II, 80125 Naples, Italy; frcalise@unina.it \\ 2 Department of Building, Civil, and Environmental Engineering, Concordia University Montreal, \\ Montreal, QC H3G 1M8, Canada; ursula.eicker@concordia.ca (U.E.); juergen.schumacher@concordia.ca (J.S.) \\ * Correspondence: maria.vicidomini@unina.it
}

Received: 23 June 2020; Accepted: 28 July 2020; Published: 31 July 2020

\begin{abstract}
The aim of the present paper is to develop a reliable and accurate model of the wastewater biochemical treatment process and to explore the behaviour through a general dynamic simulation environment, namely the INtegrated Simulation Environment Language (INSEL), for the analysis of the energy demand of the whole wastewater treatment plant. In particular, the presented model pays special attention to the chemical kinetics involved in the activated sludge process for the reduction of nitrogen and carbon compounds. According to the best practices, the plant configuration considered in this work includes the denitrification-nitrification process, performed by completely mixed reactors. In particular, the process analysed in this paper is based on the Ludzak-Ettinger process. The biological process is simulated according to the well-known method widely used in the literature, namely the Activated Sludge Model No 1 (ASM1). The model includes a set of equations for the calculation of aerobic growth of heterotrophs, anoxic growth of heterotrophs, aerobic growth of autotrophs, decay of autotrophs, ammonification of soluble nitrogen, hydrolysis of entrapped organics, and hydrolysis of entrapped organic nitrogen. All these equations, along with energy and mass balances, are solved by the explicit Euler method. The developed model is validated using literature data, showing a great accuracy (deviation below 1\%). As for the temperature, results show that, between 15 and $25^{\circ} \mathrm{C}$, in the initial part of the process, transport effects dominate the consumption ones. When the temperature is higher than $30^{\circ} \mathrm{C}$, nitrate consumption is so fast that biomass growth is limited by this effect. Conversely, in case of low temperatures $\left(5-10^{\circ} \mathrm{C}\right)$, biomass growth is not limited by nitrate availability. Finally, results also showed that temperature significantly affects the denitrification process, whereas the effect on the oxygen is lower.
\end{abstract}

Keywords: activated sludge process; numerical modelling; wastewater treatment plant

\section{Introduction}

The majority of Countries implemented several actions to avoid the disposal of wastes and wastewater without treatment in land and water bodies, since it determines harmful effects on the health of environment, humans and animals [1]. Conventional wastewater treatment plants are extremely intensive energy consumers [2], since their processes require large amounts of electrical and thermal energy. Data from Germany as well as from Italy show that electricity demand for wastewater treatment accounts for about $1 \%$ of total consumption of the country [3]. In particular, the high energy consumption in wastewater treatment plants is mainly due to their heavy mechanical systems, such as pumps and aeration systems, for moving and treating wastewater [4]. Therefore, due to the high energy consumption of the wastewater treatments plants, more sustainable and energy-efficient treatments have been developed [5]. For example the production of biological energy by-products, such as biogas or biomethane, is obtained by the conversion of wastewater into a stabilised waste [6]. Biomethane 
can be used to supply biomethane vehicles, combined heat and power plants [7], that in turn can produce electricity and heat [8], useful energy vectors for municipal district networks [9]. Therefore, according to this paradigm, wastes are no longer an energy and environmental issue, since they become a sustainable energy source [10]. Furthermore, such an arrangement is also economically very interesting, due to the savings in terms of waste disposal and to the incomes related to the produced energy [11].

Considering that one of the main costs and energy consumptions of the wastewater treatment plants is due to the biological aerobic treatment, it is important to evaluate the related energy demand and define potential energy measures to reduce it. This treatment, the well-known activated sludge process [12], is equipped with aeration systems, based on air blowers, providing oxygen to the aeration tanks for the reduction of nitrogen and carbon compounds. This process is widely simulated in the literature by using the Activated Sludge Model No 1 (ASM1) [13], performing carbon oxidation, nitrification and denitrification. Although numerous and newer models have suggested several modifications (see references [14,15]) for the mathematical modelling of activated sludge process, these have yet to be fully embraced by the international community [16]. All these models implemented direct numerical integration of the governing equations, so a system of coupled non-linear differential equations is obtained [12]. In this work, the numerical solution technique is designed so that it provides adequate accuracy for each component, optimizing the computational time and by considering the mean residence time of each component into the reactor. In this way, a higher computational efficiency can be obtained by using different time steps for the various differential equations of the model.

Therefore, the present paper focuses on the development of a reliable and accurate simulation model of the activated sludge process based on the most widespread configuration of the Ludzack-Ettinger layout in steady state conditions, including the denitrification, combined nitrification and secondary settling processes. The aim is the validation of the user-developed model, which will be integrated in a general dynamic simulation environment for the analysis of municipal energy networks, namely INSEL (INtegrated Simulation Environment Language) [3]. This is a general dynamic simulation tool, developed at the University of Concordia, which allows one to model any energy system by using built-in components libraries or employing user-developed models. The future aim of this work will be the evaluation of the energy demand of the whole wastewater plant and the potential production of biogas by considering its use in novel and/or existing municipal district networks. Therefore, the whole model will accurately take into account the modelling of buildings load demands, weather conditions, components modelling, control strategies, etc. Most of these components/phenomena models are available in several simulation platforms, whereas by means of this approach, all the phenomena and processes will be available in a unique simulation tool.

\section{Method}

This section presents the analysis of wastewater biochemical treatments, paying special attention to the chemical kinetics involved in the activated sludge process for the reduction of nitrogen and carbon compounds. According to the best practices, the plant configuration considered in this work includes the denitrification-nitrification process, performed by completely mixed reactors. In particular, the process analysed here is based on the Ludzak-Ettinger process, where three stages are included: anoxic, aerobic and sedimentation. The biological process is simulated according to the well-known method widely used in literature, namely the Activated Sludge Model No 1 (ASM1) [13], by means of a user-developed code. The model, reported in the Appendix A, includes a set of equations for the calculation of aerobic growth of heterotrophs, anoxic growth of heterotrophs, aerobic growth of autotrophs, decay of autotrophs, ammonification of soluble nitrogen, hydrolysis of entrapped organics and hydrolysis of entrapped organic nitrogen. All these equations, along with energy and mass balances are solved by the explicit Euler method. This method has been preferred to the Ordinary Differential Equations (ODE) solver included in the MATLAB tool. The developed model evaluates the energy demand of the process and it is validated according to the plant configuration that the 
624 action of the European Cooperation in Science and Technology proposes $[17,18]$ (COST, a reference point for the comparison of the automatic treatment control systems). The COST Action 624 is dedicated to the optimisation of the performance and cost-effectiveness of wastewater management systems. Therefore, the action is focussing on increasing the knowledge of microbiological systems. The following subsections present system layout, model and validation procedure.

\subsection{System Layout}

The most widespread configuration based on the Ludzack-Ettinger process is investigated (Figure 1), which consists of: (i) an anoxic process, the denitrification process, where the heterotrophic bacteria convert nitrates $\left(\mathrm{NO}_{3}\right)$ into ammonia nitrogen $\left(\mathrm{NH}_{3}\right.$ and $\mathrm{NH}_{4}{ }^{+}$), (ii) an aerobic process, the combined nitrification process, where the heterotrophic and autotrophic bacteria operate with dissolved oxygen in order to remove the carbonaceous substrate and ammonia nitrogen and (iii) the sedimentation process, for the removal and recirculation of the activated sludge.

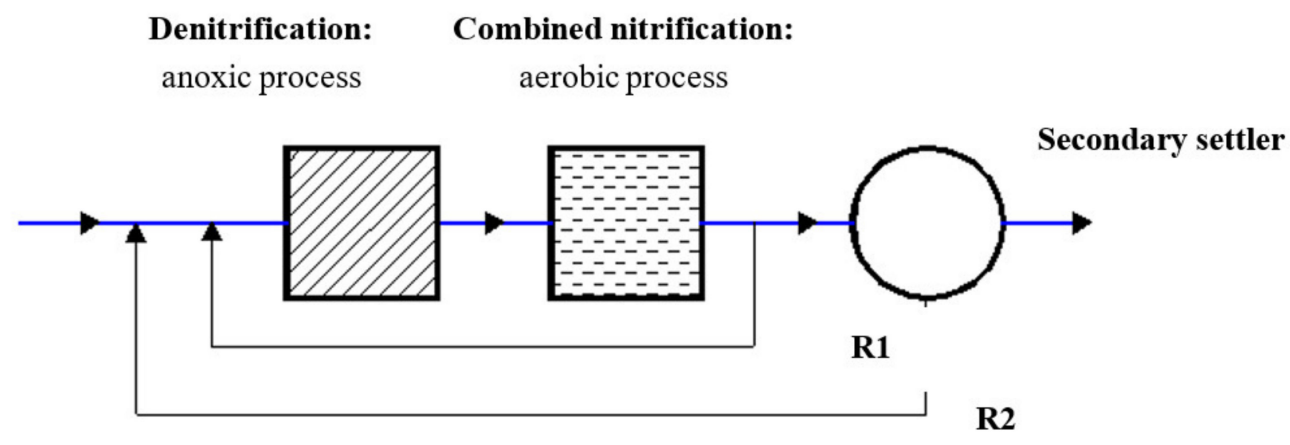

Figure 1. System layout.

Two recirculation lines are needed. Because the inlet nitrates' concentration is negligible, in order to obtain sufficient concentration values for the development of the denitrification process, the first recirculation line R1 allows one to supply nitrates obtained by the combined nitrification process to the denitrification process. Note that the denitrification process can be performed only using carbon compounds. Therefore, by means of this process, the simultaneous reduction of the nitrate and carbon substrate concentrations is obtained. Note that the denitrification process is located before the combined nitrification process, to avoid adding further organic compounds (e.g., methanol) to the process. The second recirculation line R2 is mainly proportioned for the recirculation of bacteria, although it also sends nitrogen compounds.

\subsection{Calibration and Validation Procedure}

The calibration and validation procedure of the developed code is carried out by means of the COST simulation benchmark plant and data [16], in steady state condition. The aim of the work is to develop a suitable simulation code for the biological processes to be integrated in the energy commercial software INtegrated Simulation Environment Language (INSEL). In the COST benchmark, different data are available in terms of initial and boundary conditions as well as results obtained by means of several different commercial software. The benchmark simulation plant is reported in Figure 2.

This consists of 5 biological tanks-in-series with a secondary settler. The total biological volume is $5999 \mathrm{~m}^{3}$ (tanks 1 and 2, each $1000 \mathrm{~m}^{3}$, and tanks 3, 4 and 5, each $1333 \mathrm{~m}^{3}$ ). Tanks 1 and 2 are unaerated, but fully mixed. Tanks 3,4 and 5 are aerated, with $k_{L a}$ (oxygen transfer rate $\left(\right.$ day $\left.^{-1}\right)$, provided by the blowers' manufacturers) of $10 \mathrm{hr}^{-1}$ for tanks 3 and 4 , and $k_{\mathrm{La}}$ of $3.5 \mathrm{hr}^{-1}$ for tank 5 . The concentration of dissolved oxygen for tanks 3,4 and 5 is $8 \mathrm{gm}^{-3}$ [16]. A non-reactive secondary settler with a volume of $6000 \mathrm{~m}^{3}$ (area of $1500 \mathrm{~m}^{2}$ and a depth of $4 \mathrm{~m}$ ) is subdivided into 10 layers, with a feed point at 
$2.2 \mathrm{~m}$ from the bottom (i.e., at the middle of the sixth layer). Two recirculation lines are expected: the nitrate internal recycle from the fifth to the first tank for a default flow rate of $55,338 \mathrm{~m}^{3} / \mathrm{d}$, and the return-activated sludge (RAS) recycled from the first layer of the secondary settler to the tank 1 inlet for a default flow rate of $18,446 \mathrm{~m}^{3} / \mathrm{d}$. Note that RAS is the settled biomass returned to the treatment process to provide organisms which will continue removing pollutants. Since this is a living and growing process, it will continue to build biomass. However, an uncontrolled biomass growth must be avoided. Therefore, the amount of biomass in the process is controlled by removing (wasting) a certain amount of it each day. This excess biomass removed from the secondary system is known as waste or waste-activated sludge (WAS). It is assumed that the waste is continuously pumped from the secondary settler for a default rate of $385 \mathrm{~m}^{3} / \mathrm{d}$.

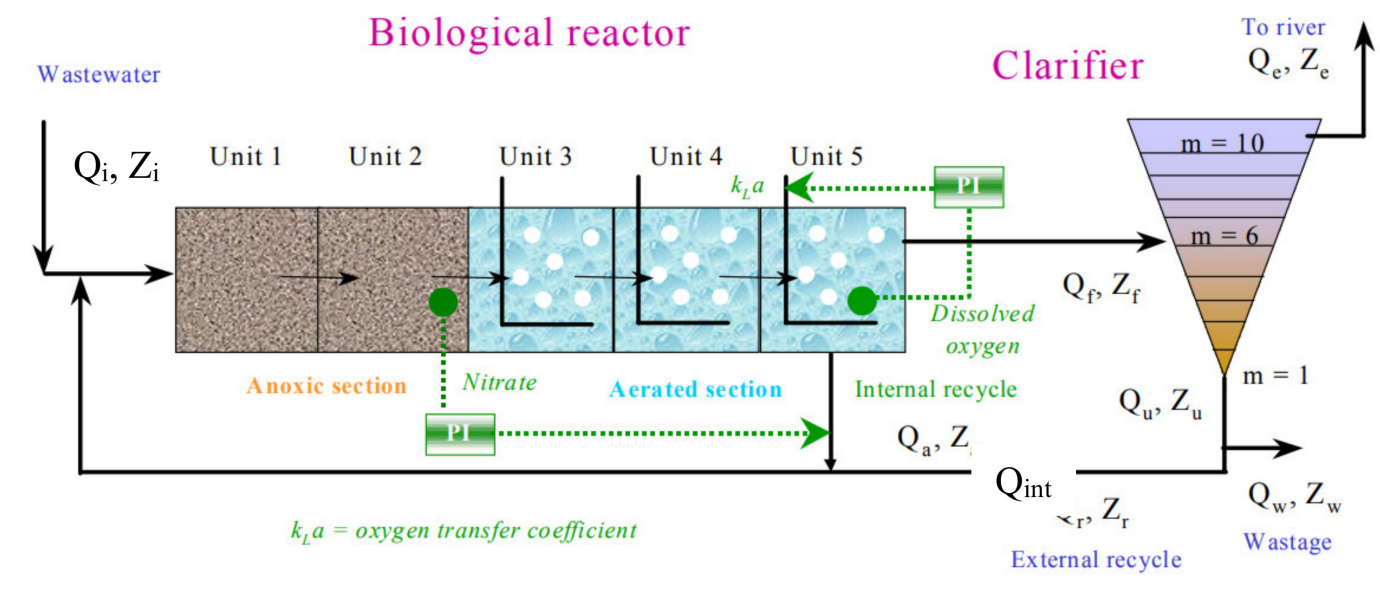

Figure 2. Benchmark simulation model plant.

The COST provides a data file including influent concentration values of 12 components of the model, reported for each 15-min interval for 14 days. As previously explained, $\mathrm{pH}$ is assumed neutral and, therefore, the alkalinity $S_{\text {alk }}$ is assumed equal to $7 \mathrm{~mol} \mathrm{~m}^{-3}$ each time step. The data include diurnal variations in flow and Chemical Oxygen Demand (COD) load and also take into account three disturbance weather events: dry weather, a storm and a rain event. In order to verify the code, the obtained results are compared with those provided by the COST after a simulation of 100-150 days, considering same boundary conditions and inputs.

\section{Results and Discussion}

In this section, results obtained from the numerical code are reported in order to show the model validation and the robustness analysis. The validation was carried out by considering the benchmark COST data obtained with other commercial software by taking into account the following boundary and initial conditions (Table 1). In particular, the validation of the anoxic tank and aerobic tank model, as well as the validation of the whole process, was performed on seven days of simulations, according to the available data. These data are included in a fully defined simulation protocol developed as a tool for evaluating activated sludge wastewater treatment control strategies. The COST simulation benchmark data are representative of three disturbances: dry weather, a storm event and a rain event. In this work, data related to a dry weather file is used. This considers normal diurnal variations in flow and COD load. The initial wastewater parameters refer to the wastewater after preliminary treatments (screenings, degritting, oil extraction and primary settling).

The results of the validation of the anoxic tank model are shown in Figure 3. The concentrations were compared with the benchmark data. The error about the inert suspended solids, $S_{I}$, in the first tank is extremely low, below $10^{-9}$ after 3 days of simulation (Figure 3a), since in the first anoxic tank, no production or consumption rate occurs. Although the oscillations reported in Figure $3 \mathrm{~b}$, seem to be large, for the particulate inert organic matter, $X_{I}$, the error tends to zero, showing values lower 
than $10^{-5}$, after the seven days of available data (Figure $3 \mathrm{~b}$ ). The figure shows that the errors are definitively acceptable according to the typical accuracy of the engineering calculations. In addition, this error is significantly lower than any possible measurement errors regarding such variables. On the other hand, a certain instability of the solution can also be detected for day 1 . However, this leads to some oscillations only in the error, not in the solution. In fact, Figure 3 displays the error for $X_{I}$, not the variable $X_{I}$ itself. The error is in the order of magnitude $10^{-5}$. Therefore, the variable $X_{I}$ is only marginally affected by these fluctuations. Additional comments have been added in the text.

Table 1. Boundary and initial conditions in the biological process.

\begin{tabular}{|c|c|c|c|c|c|c|}
\hline \multirow{2}{*}{ Concentration of } & Inflow & $\begin{array}{l}\text { Anoxic Tank } \\
1 \text { Initial }\end{array}$ & $\begin{array}{l}\text { Anoxic Tank } \\
2 \text { Initial }\end{array}$ & $\begin{array}{l}\text { Aeration Tank } \\
1 \text { Initial }\end{array}$ & $\begin{array}{l}\text { Aeration Tank } \\
2 \text { Initial }\end{array}$ & $\begin{array}{c}\text { Aeration Tank } \\
3 \text { Initial }\end{array}$ \\
\hline & \multicolumn{6}{|c|}{$\left(\mathrm{gm}^{-3}\right)$} \\
\hline $\begin{array}{l}\text { Readily biodegradable } \\
\text { substrate }\end{array}$ & 69.500 & 3.732 & 2.061 & 1.454 & 1.226 & 1.067 \\
\hline Soluble inert organic & 30.000 & 30.000 & 30.000 & 30.000 & 30.000 & 30.000 \\
\hline $\begin{array}{c}\text { Particulate inert organic } \\
\text { matter }\end{array}$ & 51.200 & 814.301 & 813.912 & 813.393 & 812.874 & 812.354 \\
\hline $\begin{array}{l}\text { Slowly biodegradable } \\
\text { substrate }\end{array}$ & 202.320 & 83.073 & 81.401 & 68.023 & 57.215 & 49.092 \\
\hline Active heterotrophic biomass & 28.170 & 2085.021 & 2083.728 & 2088.379 & 2091.048 & 2091.868 \\
\hline Active autotrophic biomass & 0 & 69.621 & 69.535 & 69.839 & 70.152 & 70.382 \\
\hline $\begin{array}{l}\text { Particulate products arising } \\
\text { from biomass decay }\end{array}$ & 0 & 227.672 & 228.044 & 228.540 & 229.037 & 229.534 \\
\hline Dissolved oxygen & 0 & 0.012 & 0.000 & 2.938 & 3.752 & 1.076 \\
\hline Nitrate and nitrite nitrogen & 0 & 1.649 & 0.543 & 2.177 & 3.881 & 5.089 \\
\hline Ammonia nitrogen & 31.560 & 17.672 & 18.135 & 16.549 & 15.029 & 13.901 \\
\hline $\begin{array}{l}\text { Soluble biodegradable } \\
\text { organic nitrogen }\end{array}$ & 6.950 & 1.319 & 0.859 & 0.914 & 0.881 & 0.808 \\
\hline $\begin{array}{l}\text { Particulate biodegradable } \\
\text { organic nitrogen }\end{array}$ & 10.590 & 5.234 & 5.235 & 4.485 & 3.872 & 3.410 \\
\hline
\end{tabular}

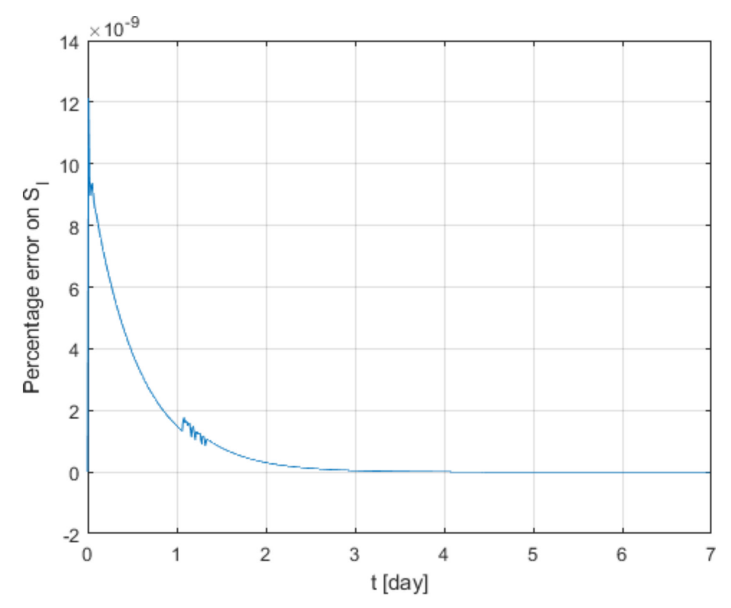

(a)

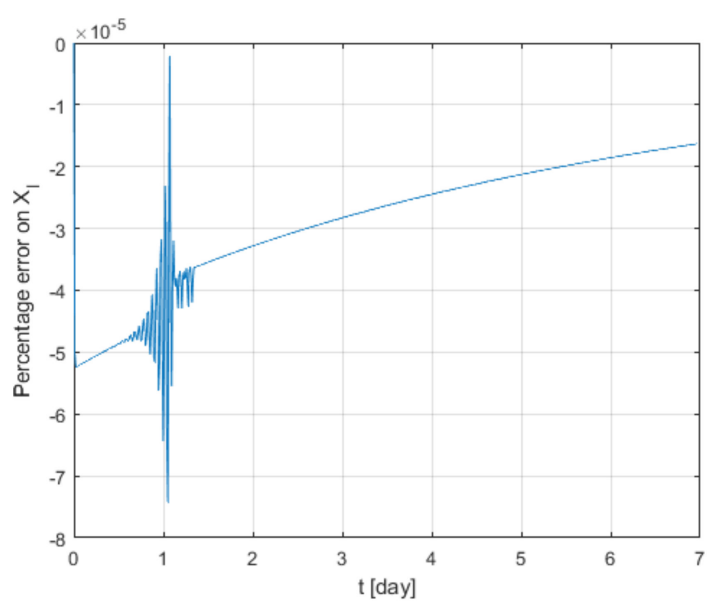

(b)

Figure 3. Percentage error in the first anoxic tank on the inert suspended solids (a) and on the particulate inert organic matter $(\mathbf{b})$.

Table 2 reports a comparison of the effluent concentrations with commercial software after 150 days of simulation, a sufficient time to reach the steady state condition.

The total suspended solids (TSS) concentrations along the settler height are also compared by obtaining satisfying results (Table 3 ).

In the anoxic tank, a really low oxygen level is obtained, as expected, because the only oxygen supply comes from the internal recirculation line; therefore, a minimum level of oxygen is detected (Figure 4). In the first seven days of simulation, the concentration of nitrite and nitrate grows due to the following reasons: (i) the nitrogen feed from sewage and (ii) the higher rate of recirculation than 
the consumption rate. The concentration of heterotrophic bacteria grows both for the recirculation and feed effect, but also for the production rate of the facultative bacteria capable to consume nitrates (Figure 4).

Table 2. Comparison of the effluent concentrations with commercial software.

\begin{tabular}{|c|c|c|c|c|}
\hline \multirow{2}{*}{ Concentration of } & Results Obtained & Biowin [4] & Simba [19] & Stoat [5] \\
\hline & \multicolumn{4}{|c|}{$\left(\mathrm{gm}^{-3}\right)$} \\
\hline Readily biodegradable substrate & 0.890 & 0.890 & 0.889 & 0.900 \\
\hline Soluble inert organic & 30.000 & 30.000 & 30.000 & 30.000 \\
\hline Particulate inert organic matter & 4.392 & 4.270 & 4.392 & 6.100 \\
\hline Slowly biodegradable substrate & 0.188 & 0.210 & 0.188 & 0.140 \\
\hline Active heterotrophic biomass & 9.782 & 9.510 & 9.782 & 6.600 \\
\hline Active autotrophic biomass & 0.573 & 0.560 & 0.573 & 0.400 \\
\hline Particulate products arising from biomass decay & 1.728 & 1.680 & 1.728 & - \\
\hline Dissolved oxygen & 0.491 & 0.500 & 0.491 & 0.500 \\
\hline Nitrate and nitrite nitrogen & 10.415 & 10.450 & 10.415 & 10.400 \\
\hline Ammonia nitrogen & 1.733 & 1.740 & 1.733 & 1.700 \\
\hline Soluble biodegradable organic nitrogen & 0.688 & 0.690 & 0.688 & 0.700 \\
\hline Particulate biodegradable organic nitrogen & 0.013 & 0.010 & 0.013 & 0.000 \\
\hline
\end{tabular}

Table 3. Comparison of the total suspended solids (TSS) concentrations in the clarifier with commercial software ( $\mathrm{n} / \mathrm{a}=$ not applicable).

\begin{tabular}{ccccc}
\hline $\begin{array}{c}\text { TSS Concentrations Along the } \\
\text { Settler Height }\end{array}$ & Results Obtained & Biowin [4] & Simba [19] & Stoat [5] \\
\hline \multicolumn{7}{c}{$\left.\mathbf{( g S s}^{-3}\right)$} \\
Layer 1 (effluent source) & 12.497 & 12.170 & 12.500 & 12.500 \\
Layer 2 & 18.113 & n/a & 18.110 & 18.100 \\
Layer 3 & 29.540 & n/a & 29.540 & 29.500 \\
Layer 4 & 68.978 & n/a & 68.980 & 68.900 \\
Layer 5 & 356.075 & n/a & 356.070 & 356.100 \\
Layer 6 & 356.075 & n/a & 356.070 & 356.100 \\
Layer 7 & 356.075 & n/a & 356.070 & 356.100 \\
Layer 8 & 356.075 & n/a & 356.070 & 356.100 \\
Layer 9 & 356.075 & n/a & 356.070 & 356.100 \\
Layer 10 (activated sludge source) & 6393.984 & 6406.030 & 6393.980 & 6394.100 \\
\hline
\end{tabular}

Optimal results in terms of percentage error with respect to the COST benchmark data were obtained for the aeration tank. In particular, in Figure 5, the concentration values of the dissolved oxygen, heterotrophic and autotrophic bacteria and carbon substrate obtained by the nitrification and carbon compounds' removal processes in the first aeration tank were reported. Due to the aerobic environment, the concentration of the dissolved oxygen is obviously high. In this tank, during the observed days, a remarkable growth of the heterotrophic bacteria concentration is obtained, from 2100 to $2425 \mathrm{gm}^{-3}$, and simultaneously, the removal of the carbon substrate from 1.45 to $1.23 \mathrm{gm}^{-3}$, according to a linear trend.

The nitrification process leads to the increase of the autotrophic bacteria concentration, from 70 to $102 \mathrm{gm}^{-3}$, and a reduction of ammonia nitrogen (Figure 6a). In fact, as reported in this figure, the process leads to the transformation of the ammonia nitrogen into nitrate and nitrite nitrogen. 


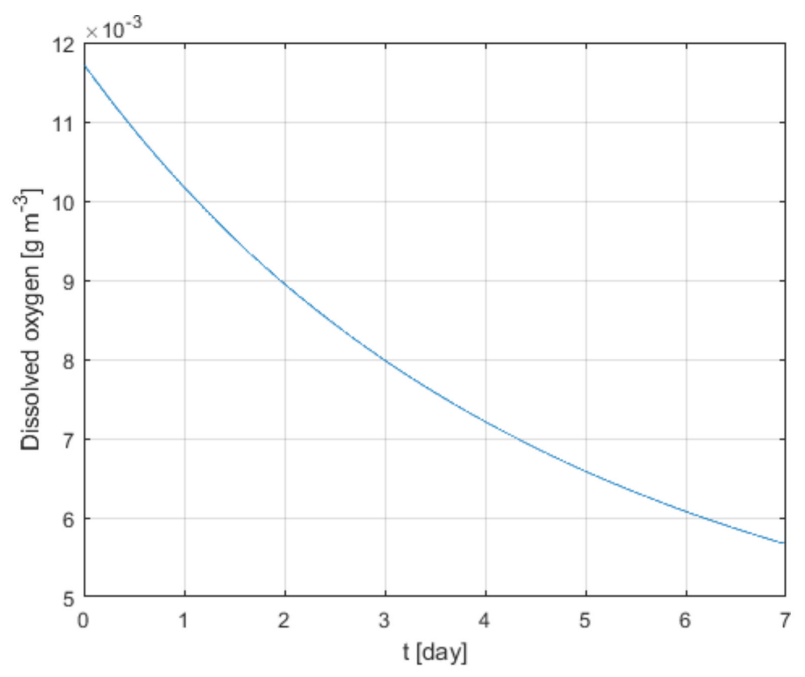

(a)

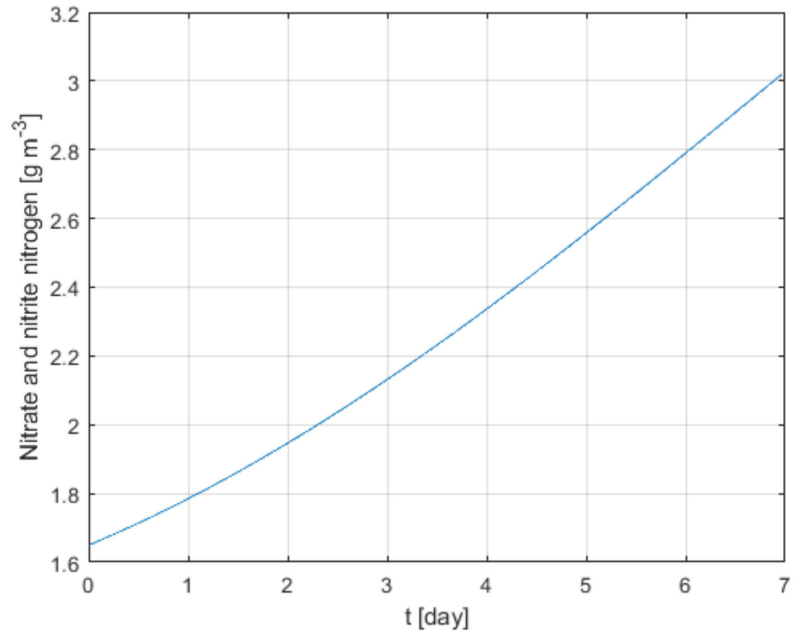

(b)

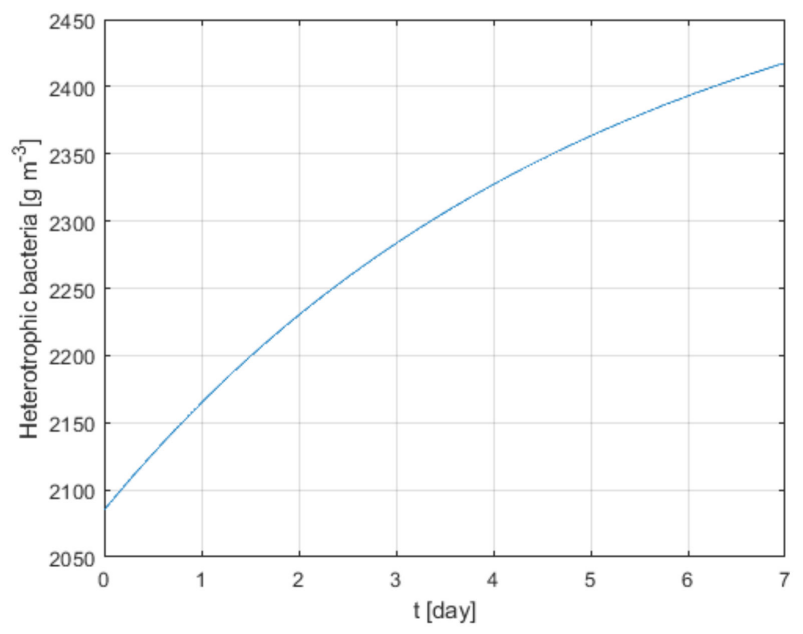

(c)

Figure 4. Dissolved oxygen (a), nitrate and nitrite (b), and heterotrophic bacteria (c) in the first anoxic tank. 


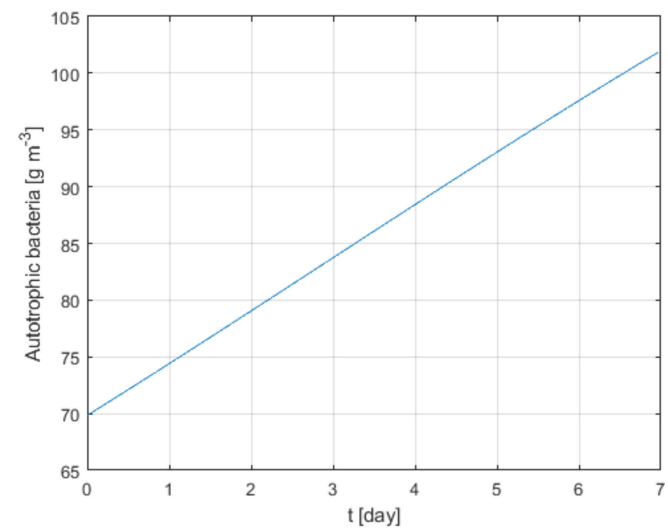

(a)

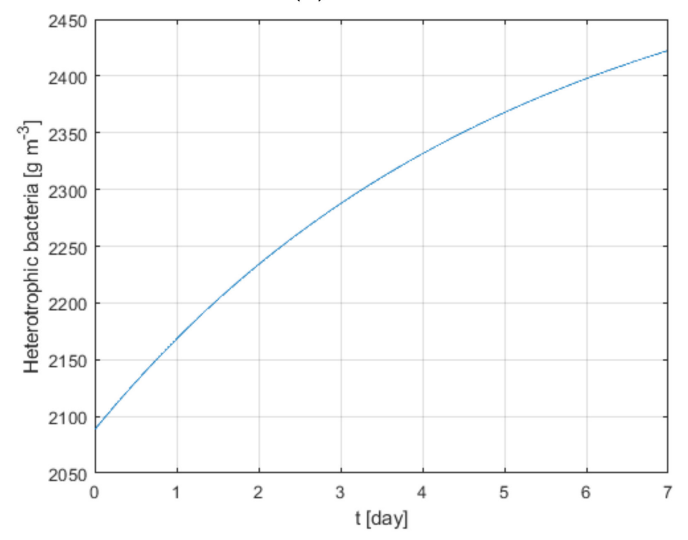

(c)

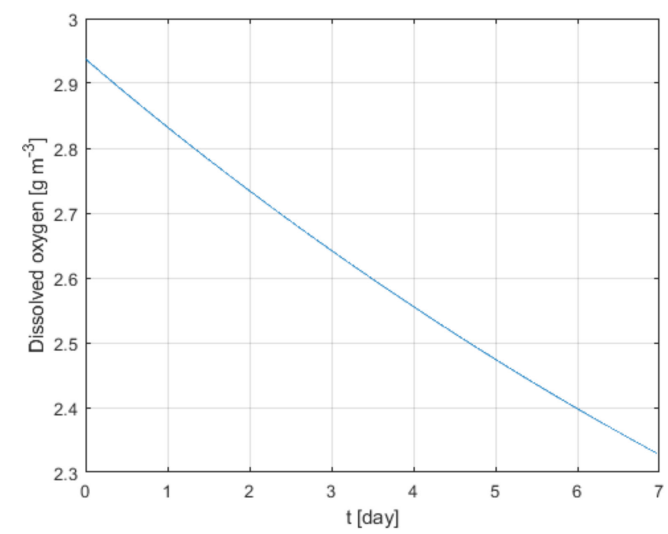

(b)

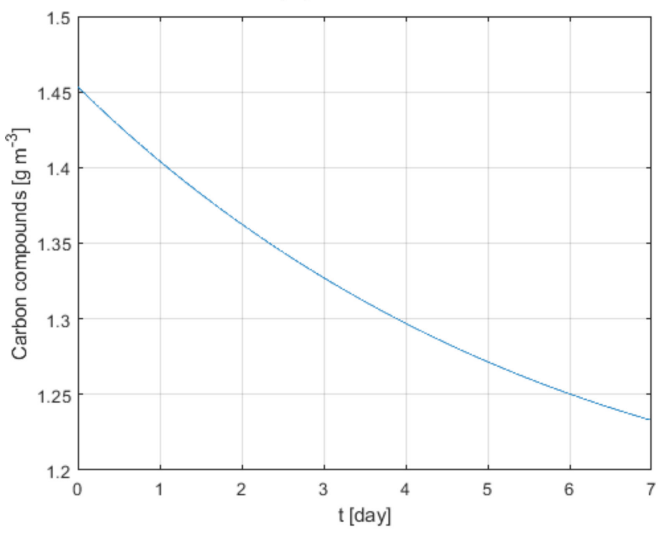

(d)

Figure 5. Dissolved oxygen (a), heterotrophic bacteria (b), autotrophic bacteria (c), and carbon substrate (d) in the first aeration tank.

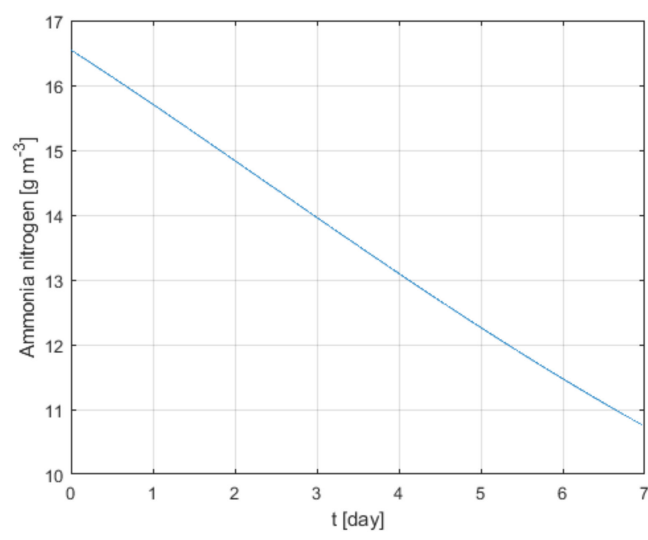

(a)

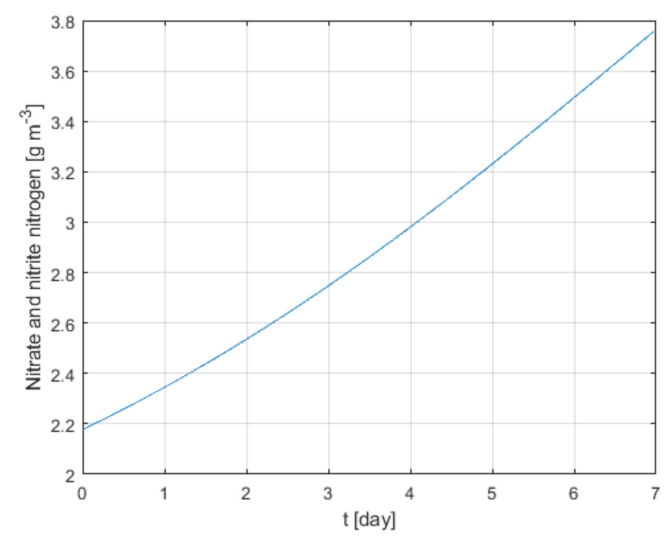

(b)

Figure 6. Ammonia nitrogen (a) and nitrate and nitrite nitrogen (b) in the first aeration tank.

\subsection{Sensitivity Analysis}

In order to prove the model robustness and the quality of the obtained results, a sensitivity analysis is performed by varying the most important kinetic-chemical parameters. For sake of brevity, the results only show the variation of: (i) $\hat{\mu}_{A}=$ the maximum autotrophic growth rate (day ${ }^{-1}$ ), (ii) $K_{S}=$ the substrate half saturation constant $\left(\mathrm{gCOD} \mathrm{m}^{-3}\right)$, (iii) $K_{N O}=$ the nitrate half saturation constant ( $\mathrm{g} \mathrm{NO}_{3}-\mathrm{N} \mathrm{m}^{-3}$ ) and (iv) the temperature of the biological treatment. By varying $\hat{\mu}_{A}$ from 0.35 and $0.65 \mathrm{day}^{-1}$ (Figure $7 \mathrm{a}$ ), the analysis showed that the autotrophs concentration in the second anoxic 
tank significantly decreases for $\hat{\mu}_{A}$ values lower than 0.45 day $^{-1}$ (typical values of water treatment plants with inlet low ammonia concentrations or no-optimal $\mathrm{pH}$ values). As expected, for low values of $K_{S}$, the concentration of heterotrophs in the last aerobic tank more rapidly reaches sufficiently high values (Figure $7 \mathrm{~b}$ ).

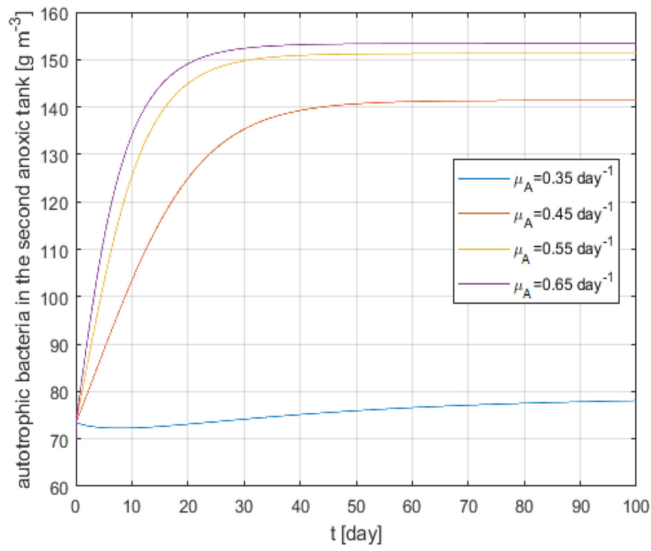

(a)

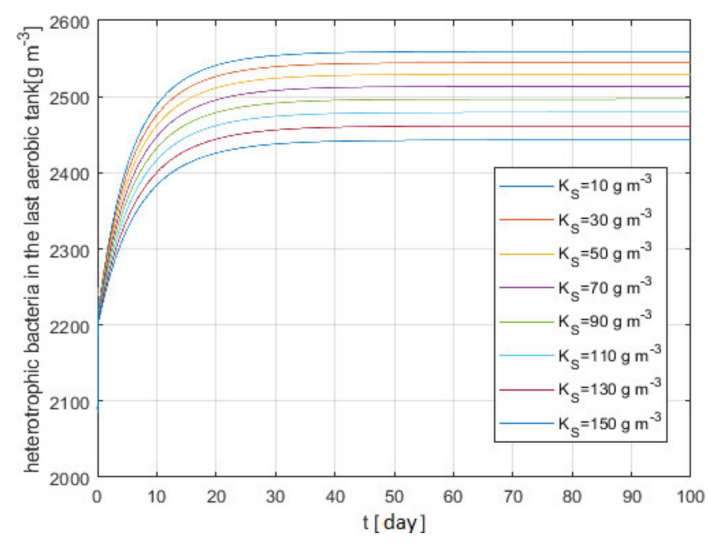

(b)

Figure 7. Autotrophs in the second anoxic tank for different values of the maximum autotrophic growth rate (a), heterotrophs in the third aerobic tank for different values of the substrate half saturation constant (b).

The value of $K_{N O}$ can be used to assess if the environment where a process occurs is anoxic. In particular, when the nitrate concentration is higher enough than the nitrate half saturation constant and the dissolved oxygen concentration is smaller enough than the oxygen half saturation constant, the tank can be modelled as anoxic. In this case, the electron acceptor is the nitrate and the switching functions included in the model are able to simulate the denitrification process, and consequently, the possible heterotrophic growth. For the typical operating range of this constant, $0.1-0.5 \mathrm{gm}^{-3}$, no significant difference was detected. Conversely, by varying $K_{N O}$ from 0.001 to $10 \mathrm{gm}^{-3}$, slight differences are obtained (Figure 8). In particular, for high values of $K_{N O}$, a decrease in the heterotrophs growth and an anoxic environment can occur.

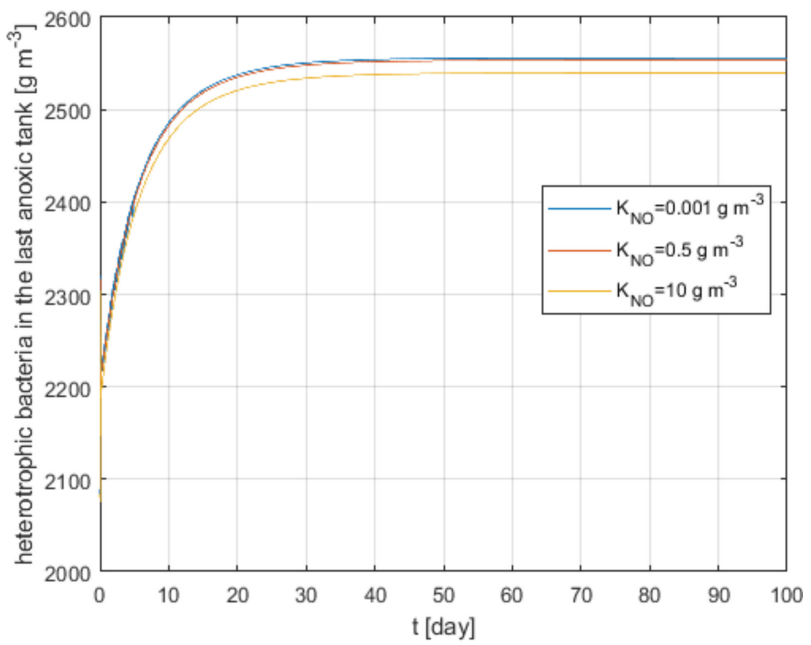

Figure 8. Heterotrophs in the second anoxic tank for different values of the substrate half saturation constant.

The temperature in the biological treatment is an important parameter affecting all the processes. In fact, according to the Arrhenius equation, the kinetics of the chemical reaction dramatically depends 
on the temperature, according to the following equation [20]: $k_{T}=k_{20} \theta^{(T-20)}$, where $\theta=1.047$ is the Arrhenius coefficient.

This parameter is varied from 5 to $35^{\circ} \mathrm{C}$, in order to simulate the potential variation of the influent temperature during the months of the year. In the anoxic tank, the study on the temperature effects is carried out by analysing the relation between the nitrates consumption (Figure $9 b$ ) and heterotrophs growth (Figure 9a).

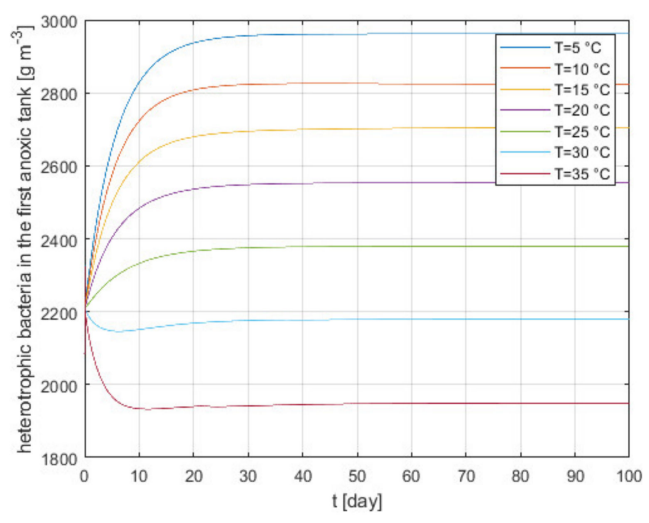

(a)

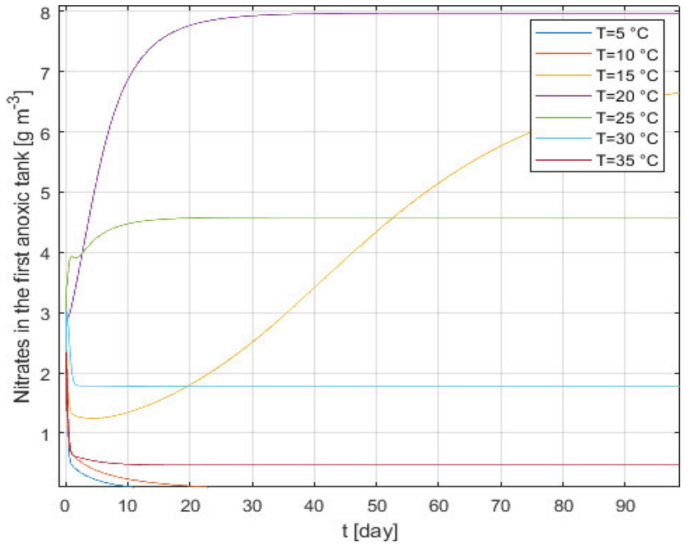

(b)

Figure 9. Heterotrophs (a) and nitrates (b) in the first anoxic tank for different temperature values.

For temperatures higher than $30^{\circ} \mathrm{C}$, the nitrates concentration goes almost to zero due to the high consumption rate. As a consequence, at high temperatures, the low nitrates concentration reduces the biomass growth and determines a low heterotrophic bacteria concentration. The trend at $20{ }^{\circ} \mathrm{C}$ is due to the following reasons: first, the nitrate feed prevails on the consumption rate of the heterotrophs, subsequently, up to 30 days, the heterotrophic bacteria concentration increases, and the consumption rate balances the nitrate feed and the stationary condition is reached. This trend is the same for temperatures between 15 and $20^{\circ} \mathrm{C}$. Conversely, for low temperatures, see isothermal curves at 5 and $10{ }^{\circ} \mathrm{C}$, the nitrate consumption rate is low, and therefore, the biomass is featured by a minor limiting effect. This determines a high heterotrophic bacteria concentration and therefore, a great consumption of nitrates, which falls to zero after 20 days (Figure 9b). Subsequently, heterotrophic bacteria concentration reaches a stationary concentration value. This effect reflects the empirical result obtained in winter operation, when high heterotrophic bacteria concentrations are measured.

For the process occurring in the aerobic environment, the force causing the oxygen supply is the difference between the saturation oxygen concentration and the effective oxygen concentration. It is well known as the saturation oxygen concentration is temperature-dependent. In particular, the higher the temperature, the lower the saturation oxygen concentration. As it is shown, between 15 and $25^{\circ} \mathrm{C}$, the dissolved oxygen concentration is high enough to determine quite high heterotrophic bacteria concentrations and low carbonaceous substrate concentrations due to the high substrate removal (Figure 10). For temperatures higher than $25^{\circ} \mathrm{C}$ or lower than $15^{\circ} \mathrm{C}$, high substrate concentrations are obtained. In the first case, this is due to a low oxygen concentration, and in the second case, to low values of maximum velocity of substrate degradation.

In the aerobic environment, the ammonia nitrogen is degraded by autotrophic bacteria, operating only with sufficient dissolved oxygen concentration values. For low temperatures, ammonia nitrogen concentrations are high (Figure 11b), because although the dissolved oxygen is sufficient for both the nitrification and carbonaceous substrate removal, the maximum growth rate parameter of autotrophs is low (Figure 12). Conversely, for high temperatures, the dissolved oxygen decreases (Figure 11a), but the consumption rate is high from a kinetic point of view. As the temperature grows, an increase of the ammonia removal by the autotrophic bacteria is obtained. 


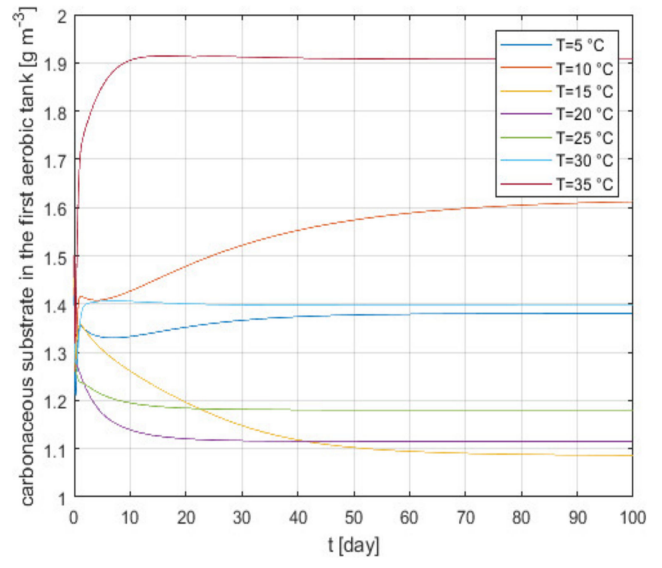

(a)

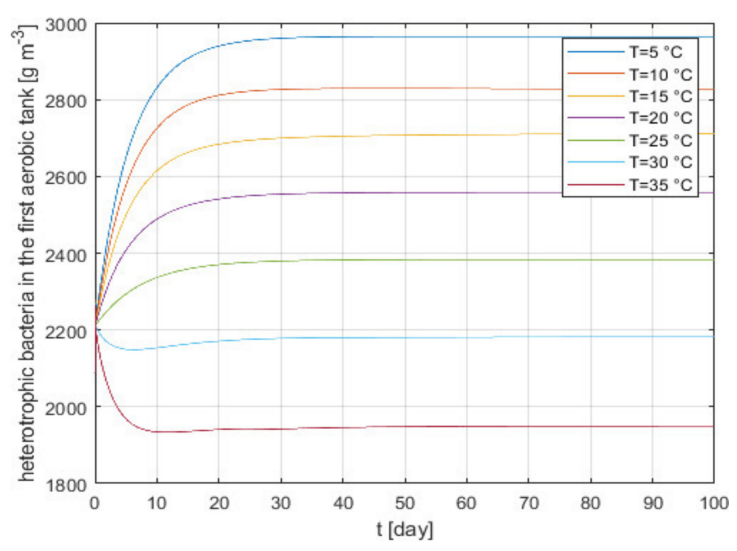

(b)

Figure 10. Carbonaceous substrate (a) and heterotrophs (b) in the first aerobic tank for different temperature values.

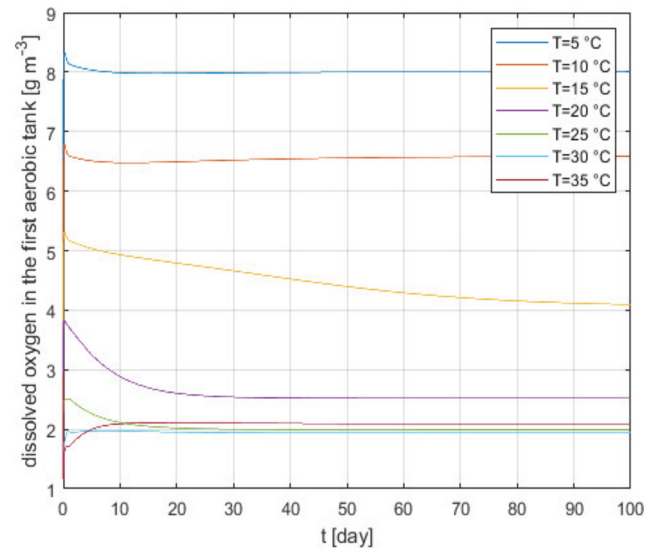

(a)

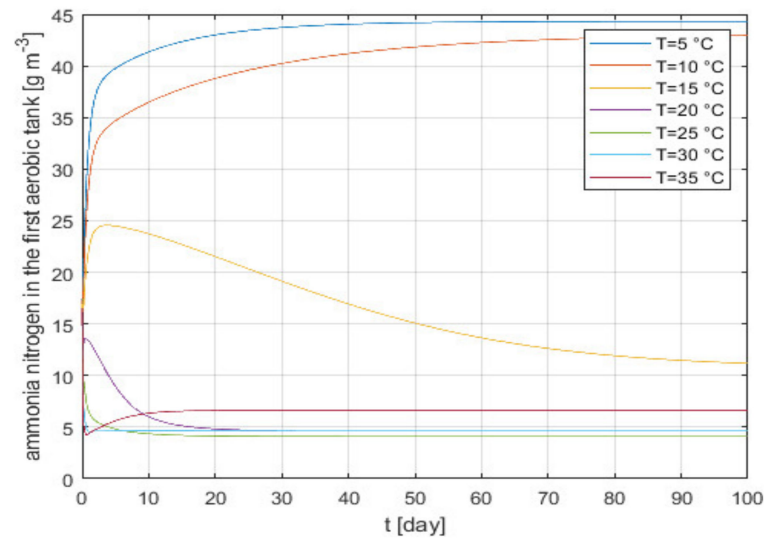

(b)

Figure 11. Dissolved oxygen (a) and ammonia nitrogen (b) in the first aerobic tank for different temperature values.

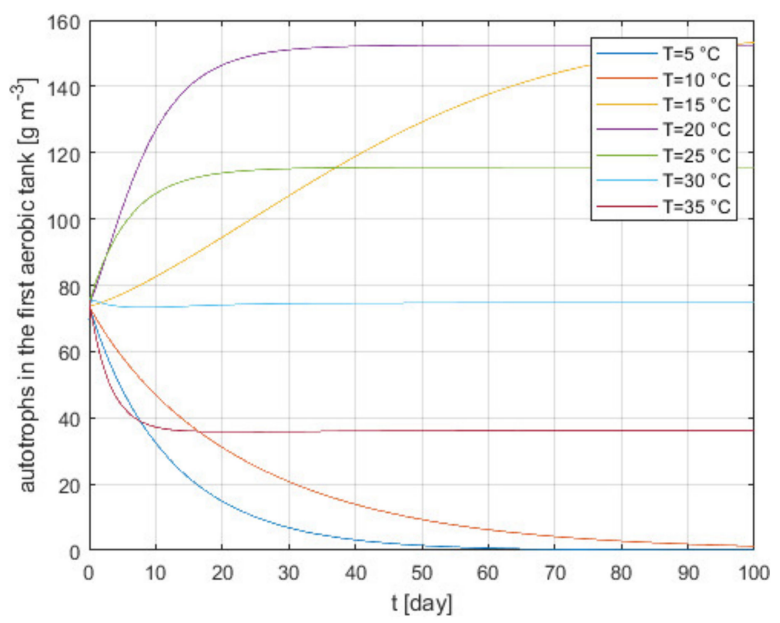

Figure 12. Autotrophs in the first aerobic tank for different temperature values.

\subsection{Energy Analysis}

This section presents the analyses of the effluent quality index (EQI) and the electric energy demand obtained by the simulations carried out using different volumes of anoxic $(1000,1250,1500$ 
and $\left.2000 \mathrm{~m}^{3}\right)$ and aerated tanks $\left(1333,1666,2000\right.$ and $\left.2600 \mathrm{~m}^{3}\right)$. In order to evaluate the best possible solutions from the energy and environmental points of view, simulations are performed by taking into account the same layout (two anoxic tanks and three aerated tanks) and same input data used for the validation process. Results are analysed after the steady-state condition is reached.

Table 4 shows the most interesting cases compared to the base case in terms of primary energy consumption of the aeration systems and $\mathrm{CO}_{2}$ emissions. The best result is obtained using anoxic tanks of $1000 \mathrm{~m}^{3}$ and aerobic tanks slightly larger than the reference case $\left(1333 \mathrm{~m}^{3}\right)$, with a reduction of $13 \%$ of primary energy consumption and $\mathrm{CO}_{2}$ emissions. Note that all the selected solutions respect the limit values of the concentrations $T S S_{e}, C O D_{e}, S_{N t o t}$ (sum of $S_{N K e}$ and $S_{N O e}$ ) and $B O D_{5, e}$ (the quantity of biodegradable organic matter contained, evaluated using the biochemical oxygen demand of microorganisms after five days) equal to 30,100,18 and $10 \mathrm{gm}^{-3}$, respectively. Therefore, EQI values are acceptable from an environmental point of view.

Table 4. Primary energy consumption and $\mathrm{CO}_{2}$ emission comparison using different tank volumes.

\begin{tabular}{|c|c|c|c|c|c|c|c|c|}
\hline $\begin{array}{c}\text { Volume } \\
\text { Tank 1, } 2 \\
\left(\mathrm{~m}^{3}\right)\end{array}$ & $\begin{array}{c}\text { Volume } \\
\text { Tank 3, 4, } 5 \\
\left(\mathrm{~m}^{3}\right)\end{array}$ & $\begin{array}{c}k_{L a} \\
\left(\text { day }^{-1}\right)\end{array}$ & $\begin{array}{c}\text { EQI } \\
(\mathrm{kg} \text { pollutions } \\
\left.\mathrm{d}^{-1}\right)\end{array}$ & $\begin{array}{l}\text { Electric } \\
\text { Demand } \\
(\mathbf{k W})\end{array}$ & $\begin{array}{l}\text { Primary Energy } \\
\text { Consumption } \\
(\mathrm{MWh} / \mathrm{y})\end{array}$ & $\begin{array}{c}\Delta \mathrm{PE} \\
(\%)\end{array}$ & $\begin{array}{c}\mathrm{CO}_{2} \\
\left(\mathrm{tCO}_{2} / \mathrm{y}\right)\end{array}$ & $\begin{array}{c}\Delta \mathrm{CO}_{2} \\
(\%)\end{array}$ \\
\hline 1000 & 1333 & 240 & 5508 & 185 & 3520 & - & 782 & - \\
\hline 1000 & 1666 & 144 & 5109 & 161 & 3061 & 13.0 & 680 & 13.0 \\
\hline 1250 & 1666 & 144 & 4941 & 163 & 3105 & 11.8 & 690 & 11.8 \\
\hline 1250 & 2000 & 120 & 4546 & 165 & 3145 & 10.7 & 699 & 10.6 \\
\hline 1500 & 2000 & 108 & 4968 & 163 & 3103 & 11.8 & 689 & 11.9 \\
\hline 2000 & 2666 & 84 & 4129 & 175 & 3339 & 5.1 & 742 & 5.1 \\
\hline
\end{tabular}

\section{Conclusions}

This work presented the development and the validation of a detailed model for the simulation of the activated sludges biological process in wastewater treatment plants. In particular, the developed model is validated according to the plant configuration that the 624 action of the European Cooperation in Science and Technology proposes (a reference point for the comparison of the automatic treatment control systems). In order to prove the model robustness and the quality of the obtained results, a sensitivity analysis was performed by varying the most important kinetic-chemical parameters and temperature. The developed model showed a great accuracy, presenting a deviation with respect to the benchmark data below $1 \%$. Results showed that biomass growth is only slightly affected by the selection of the kinetic constant, which should increase from 0.001 to $10 \mathrm{gm}^{-3}$ in order to detect a relevant effect on the growth of the biomass. As for the temperature, between 15 and $25^{\circ} \mathrm{C}$, in the initial part of the process, transport effects dominate the consumption ones. When the temperature is higher than $30^{\circ} \mathrm{C}$, nitrate consumption is so fast that biomass growth is limited by this effect. Conversely, in case of low temperatures $\left(5-10^{\circ} \mathrm{C}\right)$, biomass growth is not limited by nitrate availability. Finally, results also showed that temperature significantly affects the denitrification process, whereas the effect on the oxygen is lower. This is due to the fact that at high temperatures, ammonia is rapidly converted by the autotrophic bacteria.

The development of this model is only the first step of a longer research project on wastewater treatment plans. In fact, the final aim is the development of a comprehensive library of programming blocks for each process of the plant to be included in the INSEL energy simulation software, in order to evaluate the processes' energy demand and simulate the whole wastewater treatment plant coupled with renewable energy sources. In particular, the research project aims at investigating the integration of wastewater treatment plants in novel and/or existing district networks, considering the energy that can be produced by the biogas obtained by the wastewater plants.

Author Contributions: Conceptualization, methodology, software, validation, U.E., J.S., F.C. and M.V.; Formal analysis, investigation, resources, data curation, M.V. and F.C.; writing-original draft preparation, M.V.; 
writing-review and editing, M.V. and F.C.; visualization and supervision, F.C. All authors have read and agreed to the published version of the manuscript.

Funding: This research received no external funding.

Conflicts of Interest: The authors declare no conflict of interest.

\section{Appendix A}

\section{Appendix A.1. System Model}

The biological model used is ASM1 in the final form, published in 1987 [21]. The model considers kinetic and stoichiometric coefficients and the concentrations of the 12 components. In Table A1, a description of the main components is reported.

Table A1. ASM1 main components.

\begin{tabular}{|c|c|c|c|}
\hline & Parameter & Description & Unit \\
\hline 1 & $S_{I}$ & $\begin{array}{c}\text { Soluble inert organic matter: consists of organic compounds that do not take } \\
\text { part in the wastewater treatment processes }\end{array}$ & $\mathrm{mgCODl}^{-3}$ \\
\hline 2 & $S_{S}$ & $\begin{array}{c}\text { Readily biodegradable substrate: simple organic carbon compounds that } \\
\text { provide energy to heterotrophic bacteria }\end{array}$ & $\mathrm{mgCODl}^{-3}$ \\
\hline 3 & $X_{I}$ & $\begin{array}{l}\text { Particulate inert organic matter: undissolved organic particles such as soil } \\
\text { organic matter or other particulates isolated by sieving or filtration }\end{array}$ & $\mathrm{mgCODl}^{-3}$ \\
\hline 4 & $X_{S}$ & $\begin{array}{c}\text { Slowly biodegradable substrate: consists of relatively complex compounds } \\
\text { that must be hydrolysed to simple compounds by extracellular enzymes in } \\
\text { order to be assimilated by microorganisms }\end{array}$ & $\mathrm{mgCODl}^{-3}$ \\
\hline 5 & $X_{B H}$ & $\begin{array}{c}\text { Active heterotrophic biomass: microorganisms using organic carbon for the } \\
\text { formation of new biomass }\end{array}$ & $\mathrm{mgCODl}^{-3}$ \\
\hline 6 & $X_{B A}$ & $\begin{array}{l}\text { Active autotrophic biomass: microorganisms using carbon from carbon } \\
\text { dioxide for the formation of new biomass }\end{array}$ & $\mathrm{mgCODl}^{-3}$ \\
\hline 7 & $X_{P}$ & $\begin{array}{l}\text { Particulate products arising from biomass decay: products which are inert to } \\
\text { further biological attack after the decay of the biomass }\end{array}$ & $\mathrm{mgCODl}^{-3}$ \\
\hline 8 & $S_{O}$ & Oxygen: the oxygen concentration for the biological process & $\mathrm{mgl}^{-3}$ \\
\hline 9 & $S_{N O}$ & $\begin{array}{l}\text { Nitrate and nitrite nitrogen: products obtained by autotrophic bacteria in } \\
\text { aerobic condition and removed by heterotrophic bacteria in anoxic condition }\end{array}$ & $\mathrm{mgNl}^{-3}$ \\
\hline 10 & $S_{N H}$ & $\begin{array}{l}\mathrm{NH}_{4}{ }^{+}+\mathrm{NH}_{3} \text { nitrogen: the soluble ammonia nitrogen, assumed to be the sum } \\
\text { of the ionized (ammonium, } \mathrm{NH}_{4}^{+} \text {) and un-ionized form (ammonia, } \mathrm{NH}_{3} \text { ) }\end{array}$ & $\mathrm{mgNl}^{-3}$ \\
\hline 11 & $S_{N D}$ & $\begin{array}{l}\text { Soluble biodegradable organic nitrogen: products formed by the hydrolysis } \\
\text { of particular organic nitrogen by ammonification }\end{array}$ & $\mathrm{mgNl}^{-3}$ \\
\hline 12 & $X_{N D}$ & $\begin{array}{l}\text { Particulate biodegradable organic nitrogen: products generated from decay } \\
\text { of autotrophic and heterotrophic bacteria }\end{array}$ & $\mathrm{mgNl}^{-3}$ \\
\hline 13 & $S_{\text {alk }}$ & Alkalinity & $\mathrm{mol} \mathrm{m}^{-3}$ \\
\hline
\end{tabular}


Table A2. Process kinetics and stoichiometry for carbon oxidation, nitrification and denitrification.

\begin{tabular}{|c|c|c|c|c|c|c|c|c|c|c|c|c|c|c|}
\hline \multirow{3}{*}{ Process, $\mathrm{j}$} & \multicolumn{13}{|c|}{ Component, i } & \multirow[b]{2}{*}{ Process Rate } \\
\hline & 1 & 2 & 3 & 4 & 5 & 6 & 7 & 8 & 9 & 10 & 11 & 12 & 13 & \\
\hline & $S_{I}$ & $s_{S}$ & $X_{I}$ & $x_{S}$ & $X_{B H}$ & $X_{B A}$ & $X_{P}$ & $s_{O}$ & $s_{N O}$ & $S_{N H}$ & $S_{N D}$ & $X_{N D}$ & $S_{\text {alk }}$ & $\rho_{j}$ \\
\hline $\begin{array}{l}\text { 1. Aerobic growth of } \\
\text { heterotrophs }\end{array}$ & & $-\frac{1}{Y_{H}}$ & & & 1 & & & $-\frac{1-Y_{H}}{Y_{H}}$ & & $-i_{X B}$ & & & $\frac{-i_{X B}}{14}$ & $\hat{\mu}_{H}\left(\frac{S_{S}}{K_{S}+S_{S}}\right)\left(\frac{S_{O}}{K_{O, H}+S_{O}}\right) X_{B, H}$ \\
\hline $\begin{array}{l}\text { 2. Anoxic growth of } \\
\text { heterotrophs }\end{array}$ & & & & & 1 & & & & $-\frac{1-Y_{H}}{2.86 Y_{H}}$ & & & & $\frac{1-Y_{H}}{14 \cdot 2 \cdot 86 Y_{H}}-\frac{i_{X B}}{14}$ & $\hat{\mu}_{H}\left(\frac{S_{S}}{K_{S}+S_{S}}\right)\left(\frac{K_{O, H}}{K_{O, H}+S_{O}}\right)\left(\frac{S_{N O}}{K_{N O}+S_{N O}}\right) \eta_{g} X_{B, H}$ \\
\hline $\begin{array}{l}\text { 3. Aerobic growth of } \\
\text { autotrophs }\end{array}$ & & & & & & 1 & & $-\frac{4.57-Y_{H}}{Y_{H}}$ & $\frac{1}{Y_{A}}$ & $-i_{X B}-\frac{1}{Y_{A}}$ & & & $\frac{-i_{X B}}{14}-\frac{1}{7 Y_{A}}$ & $\hat{\mu}_{A}\left(\frac{S_{N H}}{K_{N H}+S_{N H}}\right)\left(\frac{S_{O}}{K_{O, A}+S_{O}}\right) X_{B, A}$ \\
\hline 4. Decay of heterotrophs & & & & $1-f_{P}$ & -1 & & $f_{P}$ & & & & & $i_{X B}-f_{P} i_{X P}$ & & $b_{H} X_{B, H}$ \\
\hline 5. Decay of autotrophs & & & & $F P$ & & -1 & $\int P$ & & & & & ${ }_{X X} \quad T_{P} \times P P$ & $\frac{1}{14}$ & $b_{a} X_{B, A}$ \\
\hline $\begin{array}{l}\text { 6. Ammonification of } \\
\text { soluble nitrogen }\end{array}$ & & & & & & & & & & 1 & -1 & & & $k_{a} S_{N D} X_{B, H}$ \\
\hline $\begin{array}{l}\text { 7. Hydrolysis of entrapped } \\
\text { organics } \\
\end{array}$ & & 1 & & -1 & & & & & & & & & & $k_{h} \frac{X_{S} / X_{B, H}}{K_{X}+X_{S} / X_{B, H}}\left[\left(\frac{S_{O}}{K_{O, X}+S_{O}}\right)+\eta_{h}\left(\frac{K_{O, H}}{K_{O, H}+S_{O}}\right)\left(\frac{S_{N O}}{K_{N O}+S N_{O}}\right)\right] X_{B, H}$ \\
\hline $\begin{array}{l}\text { 8. Hydrolysis of } \\
\text { entrappedorganic nitrogen }\end{array}$ & & & & & & & & & & & 1 & -1 & & $\rho_{7}\left(X_{N D} / X_{S}\right)$ \\
\hline
\end{tabular}


The adopted stoichiometric coefficients (describing the dependence between components concentrations) are: (i) $Y_{A}$, the autotrophic yield, equal to 0.24 (g $X_{B A}$ COD formed (g N oxidized) $)^{-1}$ ), (ii) $Y_{H}$, the heterotrophic yield, equal to 0.67 (g $X_{B H}$ COD formed (g COD oxidized) $)^{-1}$ ), (iii) $f_{P}$, the fraction of biomass to particulate products, equal to 0.08 (-), (iv) $i_{X B}$, the fraction of nitrogen in biomass, equal to $0.08\left(\mathrm{~g} \mathrm{~N}(\mathrm{~g} \mathrm{COD})^{-1}\right.$ in biomass $\left(X_{B A}\right.$ and $\left.\left.X_{B H}\right)\right)$ and $(\mathrm{v}) i_{X P}$, the fraction of nitrogen in particulate products, equal to $0.26\left(\mathrm{~g} \mathrm{~N}(\mathrm{~g} \mathrm{COD})^{-1}\right.$ in $\left.X_{p}\right)$. Whereas, the kinetic coefficients, describing the dependence of the process rate on the component concentration, are as follows:

$\hat{\mu}_{H}=$ the maximum heterotrophic growth rate, equal to $4.0\left(\right.$ day $\left.^{-1}\right)$.

$K_{S}=$ the saturation (heterotrophic growth), equal to $10.0\left(\mathrm{~g} \mathrm{COD} \mathrm{m}^{-3}\right)$.

$K_{O, H}=$ the half saturation (heterotrophic oxygen), equal to $0.2\left(\mathrm{~g} \mathrm{O}_{2} \mathrm{~m}^{-3}\right)$.

$K_{N O}=$ the half saturation (nitrate), equal to $0.5\left(\mathrm{~g} \mathrm{NO}_{3}-\mathrm{Nm}^{-3}\right)$.

$b_{H}=$ the heterotrophic decay rate, equal to $0.3\left(\right.$ day $\left.^{-1}\right)$.

$\eta_{g}=$ the anoxic growth rate correction factor, equal to 0.8 (-).

$\eta_{h}=$ the anoxic hydrolysis rate correction factor, equal to $0.8(-)$.

$k_{h}=$ the maximum specific hydrolysis rate, equal to 3.0 ( $\mathrm{g}$, slowly biodegradable COD ( $\mathrm{g} \mathrm{X} \mathrm{BH}_{\mathrm{COD}}$ day $)^{-1}$ ).

$K_{X}=$ the half saturation (hydrolysis), equal to 0.1 (g, slowly biodegradable COD $\left.\left(\mathrm{g} \mathrm{X}_{\mathrm{BH}} \mathrm{COD}\right)^{-1}\right)$.

$\hat{\mu}_{\mathrm{A}}=$ the maximum autotrophic growth rate, equal to $0.5\left(\mathrm{day}^{-1}\right)$.

$K_{N H}=$ the half saturation (auto: growth), equal to $1.0\left(\mathrm{~g} \mathrm{NH}_{3}-\mathrm{Nm}^{-3}\right)$.

$K_{O A}=$ the half saturation (auto: oxygen), equal to $0.4\left(\mathrm{~g} \mathrm{O}_{2} \mathrm{~m}^{-3}\right)$.

$b_{A}=$ the autotrophic decay rate, equal to $0.05\left(\right.$ day $\left.^{-1}\right)$.

$k_{a}=$ the ammonification rate, equal to $0.05\left(\mathrm{~m}^{3} \operatorname{COD}(\mathrm{g} \text { day })^{-1}\right)$.

The previous units are expressed in COD (chemical oxygen demand), i.e., the amount of oxygen necessary to oxidize all of the organic carbon completely to $\mathrm{CO}_{2}$ and $\mathrm{H}_{2} \mathrm{O}$.

The previous Table A2 has to be read in the following way. $S_{I}$ and $X_{I}$ (column 1 and 3, respectively) are not involved in any conversion processes, but their concentration in considered because it is included into the effluent COD value. $S_{S}$ (column 2 ) is removed by the growth of heterotrophic bacteria $\left(-1 / Y_{H}\right)$ under aerobic or anoxic conditions $\left(-1 / Y_{H}\right)$ and is formed by the hydrolysis of particulate organic matter $(+1)$. The slowly biodegradable substrate $X_{S}$ (column 4 ), is removed by hydrolysis $(-1)$ and formed by decay of both heterotrophic and autotrophic biomass. The decay also transforms biomass into inert particulate products; therefore, the term $f_{P}$ (the fraction of biomass to particulate products) is included $\left(1-f_{P}\right)$. As a consequence, the particulate products arising from biomass decay $X_{P}$ (column 7) are obtained by the decay of heterotrophic and autotrophic biomass. Note that the readily biodegradable material is considered to be the only substrate for growth of the heterotrophic biomass $X_{B, H}$ (column 5 ) obtained by the growth under aerobic $(+1)$ or anoxic conditions $(+1)$, whereas the growth of the autotrophs $X_{B, A}$ (column 6) only occurs under aerobic conditions $(+1)$. The considered concentration of oxygen $S_{O}$ (column 8 ) only includes biological processes, i.e., the amount of oxygen which must be provided to meet the bacteria metabolic needs. Therefore, the oxygen utilization is associated only with aerobic growth of the heterotrophic $\left(-\left(1-Y_{H}\right) / Y_{H}\right)$ and autotrophic biomass $\left(-\left(4.57-Y_{A}\right) / Y_{A}\right)$, discarding the microbial decay. This assumption differs from the more traditional approaches. The net loss of biomass associated with decay is considered by the heterotrophic yield, lower than unity. The biomass grown obtained by the substrate removal must always be lower than the biomass loss. The term 4.57 is the stoichiometric coefficient for aerobic growth of autotrophs, i.e., the theoretical oxygen demand associated to the oxidation of ammonia nitrogen to nitrate nitrogen. The nitrate and nitrite nitrogen, $S_{N O}$ (column 9), is produced by aerobic growth of the autotrophic bacteria $\left(+1 / Y_{A}\right)$ and removed during the anoxic growth of the heterotrophic biomass $\left(-\left(1-Y_{H}\right) / 2.86 Y_{H}\right)$. Note that the nitrite nitrogen is an intermediate obtained during the nitrification process, therefore, for the sake of simplicity, the model assumes that nitrate is the only oxidized form of nitrogen. The term 2.86 is the stoichiometric coefficient for anoxic growth of the 
heterotrophic biomass, i.e., the theoretical oxygen for the conversion of nitrate nitrogen to nitrogen gas $\left(\mathrm{N}_{2}\right)$. The soluble ammonia nitrogen, $S_{N H}$ (column 10), is formed by ammonification of soluble biodegradable organic nitrogen $(+1)$ and is removed by growth of the biomass. The ammonia nitrogen is consumed for the aerobic growth of the autotrophic biomass $\left(-1 / Y_{A}\right)$. However, nitrogen is also incorporated into biomass during cell synthesis and a term is included $\left(-i_{X B}\right)$ for the nitrogen used during growth of both heterotrophs and autotrophs. The soluble organic nitrogen, $S_{N D}$ (column 11), is formed by hydrolysis of particulate organic nitrogen (+1) and converted to ammonia nitrogen by ammonification $(-1)$. The particulate biodegradable organic nitrogen, $X_{N D}$ (column 12), is generated from decay of both heterotrophic and autotrophic biomass $\left(i_{X B}\right)$, minus the amount associated with the inert particulate products, and is lost by ammonification $\left(-f_{P} i_{X P}\right) . \mathrm{pH}$ of the process included in the column alkalinity, $S_{\text {alk }}$ (column 13), is considered about neutral, therefore, the model includes 12 mass balance equations to adequately simulate an activated sludge system performing carbon oxidation, nitrification and denitrification. For each process $\mathrm{j}$ of the previous table, the rate is defined in the last column of Table A2. This table represents a set of 13 differential equations (13 columns), each one including a time-variation term $\left(\frac{d S_{1}}{d t}\right)$, an inlet flow $\left(\frac{q_{\text {in }}}{V} S_{1 \text { in }}\right)$, an outlet flow $\left(\frac{q_{\text {out }}}{V} S_{1}\right)$ and generation/decay terms, which are given by the sum of products of the coefficients given in the $i$-th column of the table $\left(v_{j i}\right)$ and the respective process rate, $\rho_{j}$, as shown in the following equation:

$$
\frac{d S_{i}}{d t}=\frac{q_{\text {in }}}{V} S_{i, \text { in }}-\frac{q_{\text {out }}}{V} S_{i}+\sum_{j=1}^{8} v_{j i} \rho_{j} \quad \forall i=[1,2, \ldots, 12,13]
$$

All these equations are solved by implementing the explicit Euler method, forming a set of explicit algebraic equations. The numerical resolution of the model is based on the following differential equation:

$$
C(t+\Delta t)=C(t)+\Delta t\left(\frac{d C}{d t}\right)
$$

where $C$ represents the concentration of a generic component and $\Delta t$ is the time step adopted so that the term $C(t+\Delta t)$ is not negative, i.e., the criterion adopted to define the maximum time step avoids obtaining physically impossible solutions:

$$
\Delta t<C(t)\left(\frac{d C}{d t}\right)^{-1}
$$

Combining the relative mass balances and condition (3) for each component, the time step is

$$
\Delta t_{i}<\frac{V C_{i}}{O_{i}+K_{i}}=\theta_{i}
$$

where $\Delta t_{i}$ is the time step on component $i, V$ is the tank volume, $C_{i}$ is the concentration of the $i_{t h}$ component in the tank, $O_{i}$ is the outlet mass flow rate from the tank, $K_{i}$ is the mass flow rate consumed of the $i_{t h}$ component for biological process and $\theta_{i}$ is the mean residence time of the $i_{\text {th }}$ component in the tank, i.e., the amount of time that a component remains in the reactor. Equation (A4) demonstrates that the maximum allowable step size for each component may be different and depends on the mean residence time of the component. The numerical technique is organised so that it provides adequate accuracy for each component without wasting computational time.

Finally, the settling system is simulated considering the double exponential settling velocity function, see the equations reported in Reference [22].

\section{Appendix A.2. Aeration Energy Demand Evaluation}

In order to evaluate the energy demand of the aeration process to maintain the optimal concentration of dissolved oxygen, So, step by step, the following control strategies are implemented. 
The value $\Delta$ is iteratively calculated by the code. The code calculates the value $\Delta$ by itself within a certain number of cycles, in order to add or subtract to the $k_{L a}$ coefficient and maintain the outlet concentration, So, from the aerobic process within the recommended range of 1-4 gm ${ }^{-3}$. In particular, during each iteration, if $S o$ is less than or equal to the minimum value $\left(S_{o, \min }=1 \mathrm{gm}^{-3}\right), k_{\mathrm{La}}$ is increased by a certain value $\Delta$, iteratively calculated in order to meet the criterion that $S o$ will be higher than $1 \mathrm{gm}^{-3}$. Conversely, if $S o$ is greater than or equal to the maximum value $\left(S_{o, \max }=4 \mathrm{gm}^{-3}\right), k_{\mathrm{La}}$ is decreased by a certain value $\Delta$, iteratively calculated so that $S o$ will be lower than $4 \mathrm{gm}^{-3}$.

In this way, the optimal concentration of dissolved oxygen is step-by-step pursued, and the code reaches it by itself within a certain number of cycles.

$$
\begin{aligned}
& S_{0}<S_{0, \min } k_{L a}^{\prime}=k_{L a}+\Delta \\
& S_{0}>S_{0, \max } k_{L a}^{\prime}=k_{L a}-\Delta
\end{aligned}
$$

According to the previous control strategy, to maintain $S o$ in the recommended range of $1-4 \mathrm{gm}^{-3}$ in the tank the concentration, blowers have to provide an amount of oxygen greater than or equal to the amount evaluated as:

$$
\mathrm{O}_{2} \text { blowers }=k_{\mathrm{La}}\left(S_{0, \text { sat }}-S_{0}\right)
$$

The aeration power demand, $A P(\mathrm{~kW})$, is calculated from the $k_{L a}$ according to the following relation [22], valid for Degrémont DP230 porous disks at an immersion depth of $4 \mathrm{~m}$ :

$$
A P=\frac{S_{o, s a t}}{24 \cdot 1.8 \cdot 1000} k_{L a} V
$$

The power needed for pumping, $P P(\mathrm{~kW})$, is calculated as:

$$
P P=\frac{1}{24}\left(0.004 Q_{\mathrm{int}}+0.008 Q_{r}+0.05 Q_{w}\right)
$$

where $Q_{\text {int }}$ is the internal recirculation flow rate $\left(\mathrm{m}^{3} \mathrm{~d}^{-1}\right), Q_{r}$ is the external recirculation flow rate $\left(\mathrm{m}^{3} \mathrm{~d}^{-1}\right)$ and $Q_{w}$ is the waste-activated sludge flow rate $\left(\mathrm{m}^{3} \mathrm{~d}^{-1}\right)$.

The mixing power, $M P(\mathrm{~kW})$, is also considered. According to the COST benchmark, for all five tanks, the power is calculated only if $k_{L a}$ is lower than $20 \mathrm{~d}^{-1}$ :

$$
M P=0.005 \mathrm{~V}
$$

where $V$ is the volume of the tank $\left(\mathrm{m}^{3}\right)$. If the available power is greater than the demand $(A P+P P+$ $M P), k_{L a}$ remains equal to the previously calculated value. If the available power is lower than the demand, $k_{L a}$ is instead recalculated, but in this case, the biological process is performed at lower effluent quality. For this reason, an effluent quality index (EQI) $\left(\mathrm{kg}\right.$ pollutions $\left.\mathrm{d}^{-1}\right)$, based on a weighting of the compounds into effluent, $e$, having main influence on the quality of the receiving water, was evaluated in the model. It is defined as:

$$
E Q I=\frac{1}{1000}\left(B_{T S S} T S S_{e}+B_{C O D} C O D_{e}+B_{N K} S_{N K, e}+B_{N O} S_{N O, e}+B_{B O D 5} B O D_{5, e}\right) Q_{e}
$$

where $B_{i}$ are weighting factors, as deduced from Reference [23].

\section{References}

1. Salgot, M.; Folch, M. Wastewater treatment and water reuse. Curr. Opin. Environ. Sci. Health 2018, 2, 64-74. [CrossRef]

2. Filipe, J.; Bessa, R.J.; Reis, M.; Alves, R.; Póvoa, P. Data-driven predictive energy optimization in a wastewater pumping station. Appl. Energy 2019, 252, 113423. [CrossRef] 
3. Longo, S.; Mirkod'Antoni, B.; Bongards, M.; Chaparro, A.; Cronrath, A.; Fatone, F.; Lema, J.M.; Mauricio-Iglesias, M.; Soares, A.; Hospido, A. Monitoring and diagnosis of energy consumption in wastewater treatment plants. A state of the art and proposals for improvement. Appl. Energy 2016, 179, 1251-1268. [CrossRef]

4. Zhang, Z.; Kusiak, A.; Zeng, Y.; Wei, X. Modeling and optimization of a wastewater pumping system with data-mining methods. Appl. Energy 2016, 164, 303-311. [CrossRef]

5. Guven, H.; Dereli, R.K.; Ozgun, H.; Ersahin, M.E.; Ozturk, I. Towards sustainable and energy efficient municipal wastewater treatment by up-concentration of organics. Prog. Energy Combust. Sci. 2019, 70, 145-168. [CrossRef]

6. Shen, Y.; Linville, J.L.; Urgun-Demirtas, M.; Mintz, M.M.; Snyder, S.W. An overview of biogas production and utilization at full-scale wastewater treatment plants (WWTPs) in the United States: Challenges and opportunities towards energy-neutral WWTPs. Renew. Sustain. Energy Rev. 2015, 50, 346-362. [CrossRef]

7. Wang, J.; You, S.; Zong, Y.; Træholt, C.; Dong, Z.Y.; Zhou, Y. Flexibility of combined heat and power plants: A review of technologies and operation strategies. Appl. Energy 2019, 252, 113445. [CrossRef]

8. Salman, C.A.; Naqvi, M.; Thorin, E.; Yan, J. Impact of retrofitting existing combined heat and power plant with polygeneration of biomethane: A comparative techno-economic analysis of integrating different gasifiers. Energy Convers. Manag. 2017, 152, 250-265. [CrossRef]

9. Picardo, A.; Soltero, V.M.; Peralta, M.E.; Chacartegui, R. District heating based on biogas from wastewater treatment plant. Energy 2019, 180, 649-664. [CrossRef]

10. Calise, F.; Cappiello, F.L.; Dentice d'Accadia, M.; Infante, A.; Vicidomini, M. Modeling of the Anaerobic Digestion of Organic Wastes: Integration of Heat Transfer and Biochemical Aspects. Energies 2020, 13, 2702. [CrossRef]

11. Di Fraia, S.; Macaluso, A.; Massarotti, N.; Vanoli, L. Energy, exergy and economic analysis of a novel geothermal energy system for wastewater and sludge treatment. Energy Convers. Manag. 2019, 195, 533-547. [CrossRef]

12. Nelson, M.I.; Sidhu, H.S.; Watt, S.; Hai, F.I. Performance analysis of the activated sludge model (number 1). Food Bioprod. Process. 2019, 116, 41-53. [CrossRef]

13. Henze, M.; Grady, C.P.L., Jr.; Gujer, W.; Marais, G.V.R.; Matsuo, T. A general model for single-sludge wastewater treatment systems. Water Res. 1987, 21, 505-515. [CrossRef]

14. Hauduc, H.; Rieger, L.; Oehmen, A.; van Loosdrecht, M.C.M.; Comeau, Y.; Héduit, A.; Vanrolleghem, P.A.; Gillot, S. Critical review of activated sludge modeling: State of process knowledge, modeling concepts, and limitations. Biotechnol. Bioeng. 2013, 110, 24-46. [CrossRef] [PubMed]

15. Moretti, C.J.; Jahan, K.; Schmit, K.H.; Debik, E.; Mahendraker, V. Activated Sludge and Other Aerobic Suspended Culture Processes. Water 2011, 3, 806-818. [CrossRef]

16. Available online: https://pdfs.semanticscholar.org/b076/822899ab977bd49e271e51ae6fa8ec9ad951.pdf (accessed on 30 July 2020).

17. Available online: https://op.europa.eu/en/publication-detail/-/publication/8448ef88-37dd-4d1a-823f$3143 e 7902429$ (accessed on 30 July 2020).

18. The European Co-Operation in the Field of Scient. ific and Technical Research, Action 624: Optimal Management of Wastewater SystemsCOST Action 624 Website. Available online: http://www.ensic.inplnancy.fr/COSTWWTP (accessed on 30 July 2020).

19. Asadi, A.; Yang, K.; Mejabi, B. Wastewater treatment aeration process optimization: A data mining approach. J. Environ. Manag. 2017, 203, 630-639. [CrossRef] [PubMed]

20. Sheridan, C.; Petersen, J.; Rohwer, J. Technical note on modifying the Arrhenius equation to compensate for temperature changes for reactions within biological systems. Water $S A$ 2012, 38, 149-152. [CrossRef]

21. Henze, M.; Gujer, W.; Mino, T.; van Loosdrecht, M.C.M. Activated Sludge Models ASM1, ASM2, ASM2d and ASM3; IWA Publishing: London, UK, 2000.

22. Takacs, I.; Patry, G.G.; Nolasco, D. A dynamic model of the clarification-thickening process. Wat. Res. 1991, 25, 1263-1271. [CrossRef]

23. Alex, J.; Benedetti, L.; Copp, J.; Gernaey, K.V.; Jeppsson, U.; Nopens, I.; Pons, M.N.; Rieger, L.; Rosen, C.; Steyer, J.P.; et al. Benchmark Simulation Model no 1 (BSM1). Department of Industrial Electrical Engineering and Automation, Lund University. Available online: https://www.iea.lth.se/publications/Reports/LTH-IEA7229.pdf (accessed on 30 July 2020).

(C) 2020 by the authors. Licensee MDPI, Basel, Switzerland. This article is an open access article distributed under the terms and conditions of the Creative Commons Attribution (CC BY) license (http://creativecommons.org/licenses/by/4.0/). 